\title{
Review
}

\section{What Is New in Helicobacter pylori Diagnosis. An Overview}

\author{
Maria Pina Dore ${ }^{1,2, * \mathbb{D}}$ and Giovanni Mario Pes ${ }^{1}(\mathbb{D}$ \\ 1 Dipartimento di Scienze Mediche, Chirurgiche e Sperimentali, University of Sassari, 07100 Sassari, Italy; \\ gmpes@uniss.it \\ 2 Baylor College of Medicine, One Baylor Plaza, Houston, TX 77030, USA \\ * Correspondence: mpdore@uniss.it; Tel.: +39-079-229-886
}

check for

updates

Citation: Dore, M.P.; Pes, G.M. What Is New in Helicobacter pylori Diagnosis. An Overview. J. Clin. Med. 2021, 10, 2091. https://doi.org/ $10.3390 /$ jcm10102091

Academic Editor: Andrew Day

Received: 9 April 2021

Accepted: 11 May 2021

Published: 13 May 2021

Publisher's Note: MDPI stays neutral with regard to jurisdictional claims in published maps and institutional affiliations.

\begin{abstract}
Helicobacter pylori infection remains one of the most prevalent infections worldwide, especially in low-resource countries, and the major risk factor for peptic ulcer and gastric cancer. The "test-and-treat" strategy is recommended by several guidelines and consensus. The choice of testing method is based on patient age, presence of alarm signs and/or symptoms, use of non-steroidal anti-inflammatory drugs, as well as local availability, test reliability, and cost. Culture is the gold standard to detect $H$. pylori and, possibly, to perform susceptibility testing, however, it requires upper endoscopy and dedicated labs. Recent advances in molecular biology have provided new strategies in detecting infection and antimicrobial resistance without invasive tests. In this review we attempt to offer a comprehensive panorama on the new diagnostic tools and their potential use in clinical settings, in order to accomplish specific recommendations.
\end{abstract}

Keywords: Helicobacter pylori; testing; antibiotic resistance; molecular techniques; artificial intelligence

\section{Introduction}

Helicobacter pylori infection can be essentially detected by invasive and non-invasive tests. The choice of technique relies upon the patient's needs. Presence of alarm symptoms, use of non-steroidal anti-inflammatory drugs (NSAIDs), advanced age ( $>45-50$ years or $>60$ years) [1-4], history of premalignant conditions, or surveillance for a previous malignant disease dictates an upper endoscopy evaluation. The indication for esophagogastric-duodenoscopy allows physicians to directly observe the mucosa, to collect biopsy samples for histology examination, urease test, bacterial culture and, eventually, molecular assay. In the absence of endoscopy recommendation, non-invasive tests, such as urea breath testing or stool antigen assay, are appropriate to confirm an active infection. Serology may be used in specific settings to assist the physician in the diagnosis of bacterial infection [5]. However, the diagnostic strategy cannot prescind from the local availability, costs of the test, and the patient's preferences.

\section{Invasive Tests}

\subsection{Endoscopy}

Since the first isolation of $H$. pylori, several studies have attempted to evaluate the accuracy of standard white light endoscopy (WLE) to identify the infection, based on specific gastric mucosa features. For example, the presence of antral nodularity, observed during endoscopy, was associated with a sensitivity ranging from 39.8\% [6] to 96.4\% [7] and a specificity ranging from $83.6 \%$ [6] to $100 \%$ [8]. Additional reports identified the erythema, erosions, thickened folds or absence of rugae, mosaic appearance, with or without hyperemia, and visible submucosal vessels in the gastric mucosa as the hallmarks of $H$. pylori infection [9-12], or gastric black spots associated with $H$. pylori eradication [13]. Moreover, a study performed in Japan to evaluate the accuracy of standard endoscopy found that nodularity (89\%) and mucosal swelling (77\%) were associated with bacterial 
infection and mild atrophy [14]. However, the low interobserver agreement may be a limitation to translate gastric mucosal features into a diagnosis of specific gastritis, with or without $H$. pylori infection.

The results obtained with the narrow band imaging (NBI), which uses blue light from a laser source $(415 \mathrm{~nm})$ to highlight the vascular architecture of the gastric mucosa, seem to be more promising. Tongtawee et al. were able to predict $H$. pylori infection based on distinct patterns of gastric mucosa, observed by conventional NBI [15]. In addition, the magnifying NBI technique showed a sensitivity and specificity greater than $95 \%$ in detecting intestinal metaplasia [16], especially when a light blue crest or white opaque substance were present [17], and proved to be significantly superior $(p<0.0001)$ to serology (pepsinogen I/II ratio) [18]. Moreover, a high degree of concordance was observed between magnifying NBI and the operative link for gastritis and for gastric intestinal metaplasia assessment $[19,20]$. Interestingly, by this technique, specific morphological patterns, including reddish depressed lesions, were frequently observed in association with $H$. pylori eradication $[16,21]$. The magnifying endoscopy with NBI also proved to be superior to WLE and chromoendoscopy in the diagnosis of early gastric cancer, after H. pylori eradication [22]. However, Horiguchi et al. reported that the confocal laser endomicroscopy was more accurate than NBI for grading gastric premalignant lesions [23].

In a retrospective study conducted to detect gastric atrophy, by using blue laser imaging (BLI), the presence of a spotty pattern was associated with an active H. pylori infection, the cracked pattern with $H$. pylori eradication, and the mottled pattern with intestinal metaplasia [24]. However, the linked color imaging (LCI) results were superior to BLI in the recognition of early gastric cancer and H. pylori-negative gastritis [25]. The LCI, by improving the visualization of mucosal microstructure via contrast enhancement, was able to detect an active, or past $H$. pylori infection and associated lesions with high accuracy, although the accuracy was different for gastritis, metaplasia or atrophy [26-28]. In a comparison study between LCI and magnifying BLI-bright, the authors found the former technique highly accurate for H. pylori infection, and the latter for atrophy and intestinal metaplasia [29].

Endocytoscopy (EC), an ultra-high magnification endoscopy, is able to provide a histologic assessment in vivo. Sato et al. observed that EC patterns, such as normal pitdominant type, or the normal papilla-dominant type, visualized in the corpus and antrum, were hallmarks of normal mucosa and of the absence of $H$. pylori infection [30]. In recent years, an in vivo method was also developed, based on in situ hybridization fluorescence, enabling the diagnosis of active infection during endoscopy [31].

All recent developments of high-definition endoscopy for the diagnosis of $H$. pylori infection and detection of pre-malignant and malignant gastric lesions, allowing real-time decision-making, prompted the revision of the Kyoto endoscopic classification [32].

In the recent years, there was also an attempt to use more sophisticated tools to diagnose $H$. pylori. For example, Nakashima et al. developed an artificial intelligence approach, mimicking the brain neural network using BLI-bright and LCI. This method demonstrated to improve the accuracy and productivity of endoscopic examination, with respect to WLI, with a sensitivity for BLI-bright and for LCI of 96.7\% [33]. In a recent meta-analysis, the artificial intelligence algorithm demonstrated to be an accurate tool for the prediction of $H$. pylori infection during endoscopic procedures, although, the authors concluded that the real application needs to be evaluated in clinical studies [34]. Figure 1 shows some gastric mucosa features associated with $H$. pylori infection in different studies. 

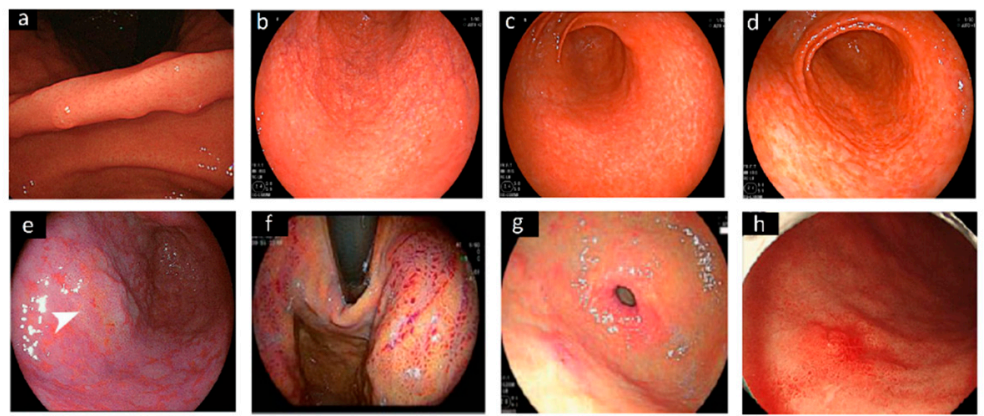

Figure 1. Images of different endoscopic patterns related to H. pylori infection. Specific features of the gastric angulus (a) in a 30-year-old man H. pylori-positive [14]. Gastric antrum showing (b) a "spotty pattern", (c) a "cracked pattern" and (d) a "mottled pattern" observed by white light endoscopy [24]; (e) orange lesion (arrow), suggestive of early gastric cancer in the antrum, surrounded by spread intestinal metaplasia [25]. By using linked color imaging (f) the gastric fundus [28], and (g) the antral mucosa appeared massively red [29]. (h) Reddish, depressed lesion observed in the greater curvature with conventional white light endoscopy 36 months after $H$. pylori eradication [23].

\subsection{Histology}

The examination of gastric mucosal biopsy specimens remains the gold standard for the detection of $H$. pylori, with a sensitivity of $95 \%$ and a specificity of $98 \%$. In addition, it enables the visualization of gastric morphology at any time. However, in order to obtain an accurate diagnosis, two antral biopsies, one from the gastric angulus, and two biopsies from the corpus, are necessary [35]. For example, in a series of 213 patients, detection of atrophic gastritis and intestinal metaplasia were missed in $8 \%$ and $3 \%$ of cases, respectively, when biopsy samples were not collected from the angulus [36]. As the widespread use of proton pump inhibitors (PPIs) may result in atypical presentation of gastritis, or in density variation of bacteria at different sites [37], the accuracy of histologic diagnosis of H. pylori infection can be improved by using special staining techniques, specific immune stain, or digital pathology [38,39]. However, a recent study reported a high percentage (94\%) of $H$. pylori detection with the standard hematoxylin-eosin staining, compared with special staining [40].

\subsection{Rapid Urease Test}

Upper endoscopy also allows to collect biopsy specimens for urease testing. The method takes advantage from the presence of pre-formed urease by the organism and, in media containing urea, the enzyme releases ammonia, increasing the $\mathrm{pH}$ and resulting in a color change of the medium.

The urease test is rapid (RUT), easy to perform, highly specific, and inexpensive for H. pylori diagnosis. However, RUT requires a high density of bacteria, for example, in the standard commercial kits, at least a $10^{4}$ bacterial load in the gastric specimens is required [41]. False-negative results may occur with recent use of antibiotics, bismuthcontaining compounds, PPIs, especially omeprazole and lansoprazole, and in children younger than five years [42]. To collect biopsies from the corpus, rather than from the antrum, or combining antral and corpus biopsies, has been shown to enhance RUT sensitivity $[43,44]$. On the other hand, Dechant et al. reported a higher sensitivity of RUT compared to histology for the detection of $H$. pylori infection in patients exposed to PPI or antibiotics [45]. Similar results were reported for a liquid RUT, the preOx-HUT, from a multicenter prospective study. Compared with histology, the preOx-HUT showed a sensitivity and specificity of $85 \%$ and $94 \%$, respectively. More importantly, the concomitant PPI-use did not influence test accuracy [46]. In addition to false negative, false-positive RUT may also occur in the presence of urease positive bacteria [41]. The gastric samples used for RUT can be re-used for molecular testing in order to identify bacterial resistance. 
However, compared with histology, RUT does not allow to establish a correct follow up of the patient.

\subsection{Culture}

In addition to histological examination and RUT, upper endoscopy offers the opportunity to collect gastric specimens for bacterial culture, susceptibility testing and, eventually, organism genotyping. Although culture is highly specific, it has a low sensitivity, as H. pylori is difficult to grow, and experienced laboratories are required. Sensitivity may be improved by sending the specimen to the laboratory within $30 \mathrm{~min}$ from collection, using a pre-heated $35^{\circ} \mathrm{C}$ blood agar (BD Diagnostics, Sparks, MD, USA) and a helicobacterselective agar, containing the antibiotics colistin and polymyxin (Hy-Laboratories, Rehovot, Israel). A longer incubation period (14 days) in microaerophilic conditions (CampyGenTM, Oxoid, Hampshire, UK), at a temperature of $35^{\circ} \mathrm{C}$, the addition of hydrogen in the atmosphere, or to treat specimens with trypsin may be an additional shrewdness [47-50].

\section{Non-Invasive Tests}

Non-invasive tests can be divided into those able to detect an active infection, such as the urea breath test and stool antigen test, and those able to provide information on current or prior H. pylori infection, without discrimination.

\subsection{Urea Breath Test}

The ${ }^{13} \mathrm{C}$-urea breath test (UBT) is the non-invasive method of choice to determine H. pylori status when available. Similarly to RUT, the test takes advantage from the urease produced by the bacteria, which is able to hydrolyze urea generating $\mathrm{CO}_{2}$ and ammonia. The urea substrate is enriched with a labeled carbon isotope, that may be non-radioactive $\left({ }^{13} \mathrm{C}\right)$ or radioactive $\left({ }^{14} \mathrm{C}\right)$ and ingested, usually, with a test meal to prolong the permanence of urea in the stomach. Breath exhaled samples are collected in proper tubes before and after urea ingestion. Even though the dose of radiation is small in the ${ }^{14} \mathrm{C}$-UBT, the nonradioactive ${ }^{13} \mathrm{C}$ test is routinely preferred. The test is also used to ascertain the eradication and it is recommended for the "test-and-treat" strategy in dyspeptic patients [1]. The test could also be successfully applied to patients with partial gastrectomy, especially when performed with the patient in the right position [51].

The ${ }^{13} \mathrm{C}$-UBT shows high sensitivity (95\%) and specificity (95\% to $\left.100 \%\right)$ [52]. A review comparing diagnostic accuracy of non-invasive tests against histology, including 99 studies, reported a sensitivity of $94 \%, 92 \%, 84 \%$, and $83 \%$ for the ${ }^{13} \mathrm{C}-\mathrm{UBT},{ }^{14} \mathrm{C}-\mathrm{UBT}$, serology and for the stool antigen test, respectively, estimated at a specificity of $90 \%$ [53]. The high accuracy of ${ }^{13} \mathrm{C}$-UBT was also confirmed in a meta-analysis, including 15 studies performed in Asia. The sensitivity and specificity results were excellent, notwithstanding the heterogeneity observed across all studies [54].

The ${ }^{13} \mathrm{C}$-urea is available on the market in different formulations, such as powder, capsules and tablets ranging between 50 and $100 \mathrm{mg}$, however the cost may be expensive for low-income countries. Coelho et al. set up a cheaper Brazilian substrate for the UBT that showed a similar diagnostic accuracy compared with the commercial formulation, making the ${ }^{13} \mathrm{C}$-UBT potentially more widely available in the country [55]. To improve results, several test meals have been used in different studies across several countries, however, the citric acid or malic acid enhances ${ }^{13} \mathrm{C}$-UBT performance, increasing urease activity in the presence of bacteria [56]. For example, in dyspeptic patients chronically exposed to esomeprazole $40 \mathrm{mg}$ daily, ${ }^{13} \mathrm{C}$-UBT with a test meal containing $5.5 \mathrm{~g}$ powder mixture of citric, malic and tartaric acid $\left(\operatorname{Refex}{ }^{\circledR}\right)$, demonstrated to have a sensitivity and specificity of $92.45 \%$ and $97.96 \%$, respectively, per-protocol analysis, after a one day break in medication [57]. However, quantitative results may be influenced by sex, age, body mass index; especially obesity, smoking, gastric atrophy and intestinal metaplasia, and even by socioeconomic status [58-60]. Although the most used cutoffs, expressed as delta over baseline (DOB), are 2\%o, 2.4\% , 2.5\% and 5\% [61], in a large community-based intervention 
trial, conducted in Linqu County, China, on 21,639 subjects included in the analysis, the optimal DOB cutoff was reported to be $3.8 \%$ with $75 \mathrm{mg}$ of ${ }^{13} \mathrm{C}$-urea [62]. Similarly, in a retrospective study performed on 234,831 patients, cluster analysis demonstrated that the ${ }^{13} \mathrm{C}$-UBT missed 2180 positive patients adopting the DOB cutoff of $3.5 \%$ recommended by the manufacturer [63]. Interestingly, an additional study reported that high DOB values may predict failure when a traditional triple therapy is used [64]. Recently, a study demonstrated that when shortening the testing time to $15 \mathrm{~min}$ by BREATHQUALITY UBT (AB Analitica, Padua, Italy), the resulting accuracy was comparable with 30 min standard testing time [65].

To analyze labeled ${ }^{13} \mathrm{CO}_{2}$, several detector devices are available on the market. One of the most recent, the BreathID Hp Lab System (Exalenz Bioscience Ltd., Modiin, Israel), was evaluated in a study in pre-treated patients and to assess $\mathrm{H}$. pylori eradication; in both cases diagnostic accuracy was excellent, according to histology and RUT [66]. The performance of BreathID Hp was comparable with the IRIS-Doc2 (Wagner Analysen-Technik, Bremen, Germany, now Mayoly Spindler Group, Chatou, France) in a prospective study when the same test protocol was used [67]. Among the instruments suggested to provide ${ }^{13} \mathrm{C}-\mathrm{UBT}$ in-the-office, is the Otsuka device [68]. The instrument, through infrared spectroscopy, measures the ${ }^{13} \mathrm{CO}_{2} /{ }^{12} \mathrm{CO}_{2}$ ratio directly from the bags used to collect breath samples. Although it is very easy to use, the UBiT kit; (Otsuka Pharmaceutical, Tokyo, Japan; cutoff value: $2.5 \%$ ) was criticized for its poor specificity in confirming $H$. pylori status after eradication [69]. The reliability of the UBiT kit was rescued by Ramirez-Lazaro et al. [70]. In their study, the authors demonstrated that false positive results obtained by UBiT were actually true positives, when the analysis was complemented by PCRs amplifying genomic ureA and $16 \mathrm{~S}$ rDNA [70].

\subsection{Stool Antigen Test}

To culture H. pylori from feces is very difficult and time consuming [71], on the contrary non-invasive tests able to detect $H$. pylori antigen in stool specimens are simple to perform and large head-to-head comparisons with other tests demonstrated the high diagnostic accuracy of this approach [72]. The first to have been introduced was the Premier Platinum HpSA, Meridian Diagnostics, Inc., Cincinnati, OH, USA [73] and several assays are already available, the more recent ones are listed in Table 1.

Table 1. Most recent stool antigen tests and their reported sensitivity and specificity.

\begin{tabular}{|c|c|c|c|c|}
\hline Brand & Based on & Sensitivity & Specificity & Reference \\
\hline $\begin{array}{l}\text { LIAISON H. pylori SA assay } \\
\text { (DiaSorin, Saluggia, Italy) }\end{array}$ & $\begin{array}{l}\text { chemiluminescent } \\
\text { immunoassay }\end{array}$ & $\begin{array}{l}90.1 \\
95.5\end{array}$ & $\begin{array}{l}92.4 \\
97.6\end{array}$ & Ramirez-Lazaro et al., 2016 [70] \\
\hline $\begin{array}{c}\text { Genx H. pylori card test } \\
\text { (Genx Bioresearch, Kocaeli, } \\
\text { Turkey) }\end{array}$ & $\begin{array}{c}\text { monoclonal } \\
\text { immunochromatographic } \\
\text { assay }\end{array}$ & 51.6 & 96.0 & Korkmaz et al., 2015 [74] \\
\hline $\begin{array}{c}\text { Uni-Gold }^{\mathrm{TM}} \text { H. pylori } \\
\text { Antigen (Trinity Biotech, } \\
\text { Bray, Ireland) }\end{array}$ & $\begin{array}{c}\text { monoclonal lateral flow } \\
\text { immunochromatographic } \\
\text { assays }\end{array}$ & 83.2 & $87-89.3$ & Lario et al., 2016 [75] \\
\hline $\begin{array}{l}\text { RAPID Hp StAR (Oxoid } \\
\text { Ltd., Hampshire, UK) }\end{array}$ & $\begin{array}{c}\text { monoclonal lateral flow } \\
\text { immunochromatographic } \\
\text { assays }\end{array}$ & $94-95$ & $77.1-84.7$ & Lario et al., 2016 [75] \\
\hline $\begin{array}{c}\text { ImmunoCard STAT! HpSA } \\
\text { (Meridian Diagnostics, } \\
\text { Cincinnati, OH, USA) }\end{array}$ & $\begin{array}{l}\text { monoclonal lateral flow } \\
\text { immunochromatographic } \\
\text { assays }\end{array}$ & $79-81.5$ & $90.8-91.6$ & Lario et al., 2016 [75] \\
\hline $\begin{array}{c}\text { IDEIA HpStAR }{ }^{\circledR} ; \\
\text { (ThermoFisher Sc., } \\
\text { Waltham, MA, USA) }\end{array}$ & $\begin{array}{l}\text { monoclonal antibodies and } \\
\text { the ELISA technique }\end{array}$ & $\begin{array}{l}\text { Before } H p \text { treatment } 93.6 \\
\text { After } H p \text { treatment } 100\end{array}$ & $\begin{array}{l}\text { Before } H p \text { treatment } 100 \\
\text { After } H p \text { treatment } 92.8\end{array}$ & Moubri et al., 2018 [76] \\
\hline $\begin{array}{l}\text { Quick Chaser H. pylori }{ }^{\circledR}, \\
\text { QCP, Misuho Medy, Tosu, } \\
\text { Japan) }\end{array}$ & immunochromatography & 92.3 & & Kakiuchi et al., 2019 [77] \\
\hline Vstrip ${ }^{\circledR} \mathrm{HpSA}$ (Meridian) & immunochromatography & $91 \%$ & $97 \%$ & Fang et al., 2020 [78] \\
\hline $\begin{array}{l}\text { ImmunoCard STAT! } \\
\text { Campy (Meridian) }\end{array}$ & immunochromatography & $76.9 \%$ & $97 \%$ & Fang et al., 2020 [78] \\
\hline
\end{tabular}


Overall, stool monoclonal antibody tests are superior to polyclonal antibody tests and demonstrated a pooled sensitivity and specificity of $93 \%$ and $96 \%$, respectively $[79,80]$. They also showed an excellent diagnostic accuracy in pediatric setting, especially when tests are ELISA based rather than immunochromatography based [81]. The use of the stool antigen test (or UBT) for the initial diagnosis of H. pylori infection and post-treatment (when endoscopy is not required), was recommended by a group of 11 experts at the Houston Consensus Conference [4].

The advantage of the UBT and of the stool antigen test is that they assess the overall content of the stomach, whereas the histology and RUT only assess a tiny biopsy specimen. Theoretically and practically, the UBT and stool antigen test are the best methods for detection of active H. pylori infection. However, any drug that diminishes H. pylori numbers below the threshold of detection can cause false negative results, particularly recent use of proton pump inhibitors, bismuth-containing compounds, or antibiotics.

\subsection{Molecular Testing}

Molecular techniques should be preferred when available. The traditional or modified real-time (RT) PCR allows for the detection of bacteria, and to screen for antibiotic sensitivity [82-84]. Moreover, the real-time PCR proved to be more accurate when compared with other techniques for the detection of $H$. pylori in patients exposed to PPI [85], and was shown to be able to detect as few as 10 copies in adults [86] and children [87]. In addition to gastric biopsies, molecular tests can be applied to the gastric mucus present on biopsy forceps placed into water or into the RUT gel [88], and the dual-priming oligonucleotidebased multiplex PCR, performed on $\mathrm{CLO}^{\circledR}$-test kits, proved to be superior to RUT and histology, in patients with a bleeding peptic ulcer [89]. Alternatively, molecular tests to detect $H$. pylori and its susceptibility to antibiotics can be performed on gastric juice [90-92]. A droplet-digital PCR may also be applied to formalin-fixed, paraffin-embedded gastric tissue to determine the presence of clarithromycin resistance [93], or by next generation sequencing to determine levofloxacin and tetracycline resistance [94] (Figure 2).

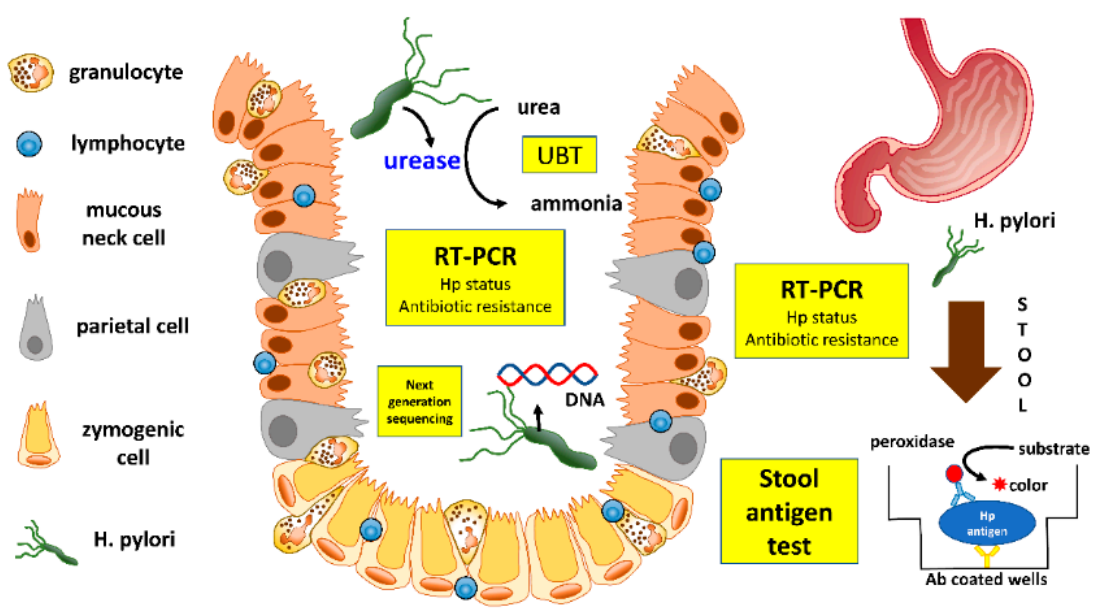

Figure 2. Invasive, non-invasive methods and molecular testing to detected H. pylori and its antibiotic resistance.

Several molecular tests have been developed in the last years to detect specific $H$. pylori antigens and/or resistance pattern in the stool (Table 2). 
Table 2. Recent molecular assays available to detected $H$. pylori and its antibiotic resistance.

\begin{tabular}{ccc}
\hline Molecular Test & H. pylori DNA Target & Reference \\
\hline $\begin{array}{c}\text { multiple genetic analysis } \\
\text { system (MGAS) }\end{array}$ & 16S rDNA and ureC & Zhou et al., 2015 [95] \\
\hline allele-specific PCR & N87I mutation in the gyrA & Trespalacios et al., 2015 [96] \\
\hline droplet-digital PCR (ddPCR) & $\begin{array}{c}\text { cagA and its EPIYA } \\
\text { phosphorylation motifs }\end{array}$ & Talarico et al., 2016 [84] \\
\hline $\begin{array}{c}\text { loop-mediated isothermal } \\
\text { amplification (LAMP) }\end{array}$ & ureC gene & Yari et al., 2016 [97] \\
\hline $\begin{array}{c}\text { TaqMan RT-PCR } \\
\text { droplet-digital PCR (ddPCR) }\end{array}$ & $\begin{array}{c}\text { A2142C, A2142G and } \\
\text { A2143G mutations }\end{array}$ & Beckman et al., 2017 [98] \\
\hline $\begin{array}{c}\text { real-time PCR (THD } \\
\left.\text { fecal test }{ }^{\circledR}\right)\end{array}$ & $\begin{array}{c}\text { 23S ribosomal RNA } \\
\text { MagNA Pure 96 (Roche) }\end{array}$ & Talarico et al., 2018 [93] \\
\hline Amplidiag ${ }^{\circledR}$ H. pylori + ClariR & $\begin{array}{c}\text { H. pylori and CLA } \\
\text { resistance mutations }\end{array}$ & Pichon et al., 2020 [101] \\
\hline
\end{tabular}

\subsection{Serology}

Unlike UBT and stool antigen testing, serology does not distinguish between an active or past infection, although in a recent study, antibody response to H. pylori proteins, such as VacA, GroEl, HcpC, CagA, Tip- $\alpha$, HP1564, and HP0175 indicates an active H. pylori infection with a high diagnostic accuracy $[102,103]$.

Detection of serum IgG against $H$. pylori is usually based on the enzyme-linked immunosorbent assays (ELISA). The latex immunoassay (Eiken Chemical Co, Ltd., or Denka Seiken Co, Ltd., Tokyo, Japan), is also employed with some advantage in terms of time consumed [104]. Several kits are available on the market and, overall, they are highly sensitive and specific. However, to maintain high diagnostic accuracy, serologic tests need to be validated locally [105], especially when the kit uses antigen strains from different geographic areas [106]. Because IgG titers decline slowly (over around six months), the test is not recommended to evaluate bacterial eradication after treatment. However, in the United States, despite the ACG and AGA guideline recommendations, serologic testing was the most commonly prescribed assay for the evaluation of $H$. pylori infection, until few years ago [107]. High serum antibody titers in subjects between 40 to 59 years old have been associated with the presence of gastric mucosa nodularity and or atrophy [108]. Similarly, serology positivity for CagA, Tip- $\alpha$, HP0175, Omp, and HP0305 can predict an increased risk of atrophic gastritis or, more in general, precancerous lesions [103,109].

\subsection{Tests on Plasma, Blood, Saliva and Urine}

The GastroPanel ${ }^{\circledR}$, especially the new-generation test, which assesses H. pylori antibodies and pepsinogen (PG) I plus PG II and gastrin-17 in the plasma simultaneously, is able to predict $H$. pylori infection and the presence of atrophic gastritis with a likelihood of $94-95 \%$ [110]. The test was reported by several authors as the most comprehensive non-invasive diagnostic test, as it avoids false and negative results, with respect to conventional tests [57,110-113]. For example, in a study performed in Korea, a decreased PG I/II ratio was significantly associated with chronic atrophic gastritis and intestinal metaplasia $(p<0.001)$ and, inversely, an increased ratio correlated with endoscopic findings, such as gastric and duodenal ulcer or nodular gastritis [111]. A similar association between a decreased PG I/II ratio and precancerous gastric conditions was also confirmed in several European countries, although the authors criticized the PG low specificity and its testing limitation for assessing gastric cancer risks [114]. Moreover, the measurement of PG I levels in the serum and the assessment of $H$. pylori infection may also be used to identify patients 
at high-risk for gastroduodenal injury induced by aspirin [115]. Interestingly, a cutoff value of PG I $\leq 31.2 \mathrm{ng} / \mathrm{mL}$ and PG I/II ratio $\leq 4.6$ was able to discriminate for a past $H$. pylori infection in patients with Group A blood in a multicenter study [116].

A plasma sample also offers the opportunity to detect circulating microRNAs (miRNAs) by molecular techniques. For example, the expression of four miR-28-3p, miR-143-3p, miR-151a-3p and miR-148a-3p were shown to be associated with H. pylori infection [117].

In contrast, the accuracy of two plasma antibody test-systems (latex agglutination and ELISA) were suboptimal when compared with histology for gastric cancer screening [118].

IgG antibodies against $H$. pylori may also be detected in dried blood spots, saliva, and urine by ELISA, with good reported accuracy [119-121]. The diagnostic performance of a rapid urine test, based on immunochromatography (RAPIRUN by Otsuka Pharmaceutical Co., Ltd., Tokyo, Japan), was evaluated in a study conducted in Thailand. The accuracy of RAPIURIN was $89.4 \%$ compared with RUT $(95.7 \%)$, histopathology $(97.9 \%)$ and culture $(97.9 \%)$, respectively [122]. In addition, a rapid urine IgG antibody test (u-HpELISA, Otsuka Pharmaceuticals Co., Ltd., Tokyo, Japan) was assessed in Japanese adolescents and the reported sensitivity and specificity were $85.7 \%$ and $100 \%$, respectively [120]. Detection of $H$. pylori in the dental biofilm and in saliva samples, evaluated in dyspeptic children by RT-PCR targeting 16S rRNA and $23 \mathrm{~S}$ rRNA genes, demonstrated to be superior to gastric biopsy specimens [123].

\section{Summary}

Physicians now have at their disposal a wide variety of diagnostic methods, which are classified into invasive and non-invasive. The choice of the test cannot prescind from the clinical scenario, local availability, knowledge of lab reliability and performance quality, costs, ongoing treatment, and patient desiderata. As a rule of thumb, it is important for the physician to confirm the diagnosis, to evaluate the presence of gastric lesions induced by the infection according to the patients' clinical history, to offer H. pylori eradication therapy, and to check treatment success.

Our approach to, and the extent of the diagnostic evaluation of a patient with uninvestigated dyspepsia is based, beyond the age of the patient on clinical presentation, on presence/absence of alarm features, ongoing treatment with NSAID and/or direct oral anticoagulants (Figure 3).

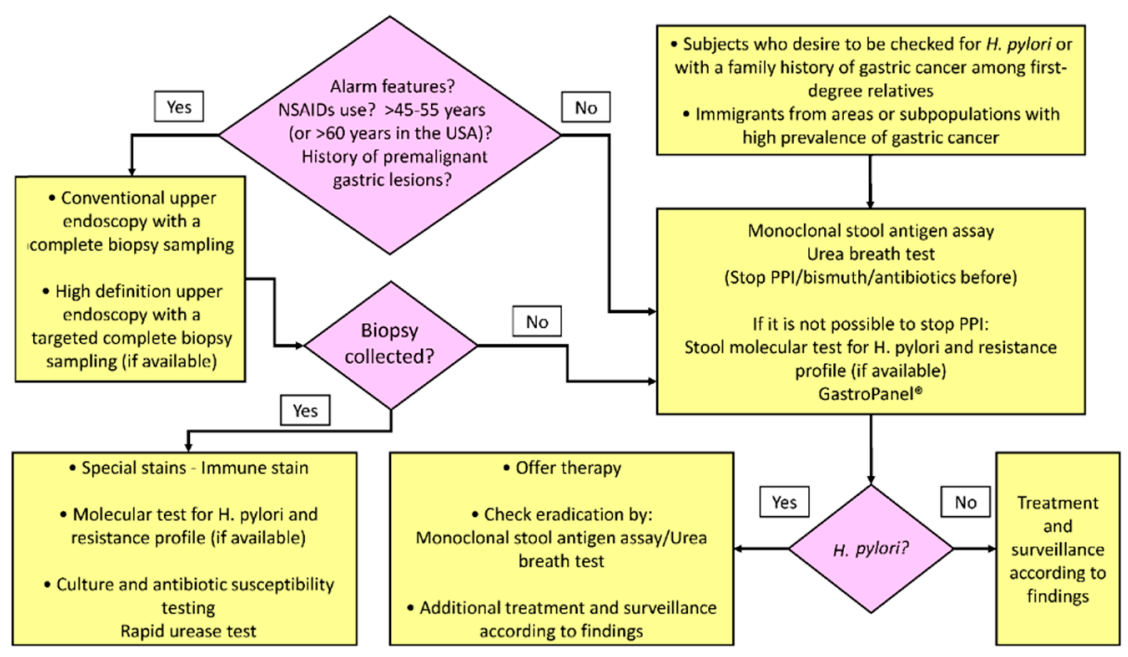

Figure 3. Diagnostic evaluation to detect $H$. pylori infection and its gastric mucosa sequelae.

According to the recommendations of major gastroenterology societies, the age cut off may range from 60-65 years in patients from resource-rich countries with a low prevalence of gastric cancer, to 45-50 years or less in patients from countries or subpopulations with a high prevalence of gastric cancer [1-4]. Under these age thresholds, in the absence of alarm symptoms and use of NSAIDs or anticoagulants, we apply a "test and treat" strategy. 
The best tests to non-invasively assess an active $H$. pylori infection are the ${ }^{13} \mathrm{C}$-UBT and the monoclonal stool antigen test, both of which are highly accurate. However, they may be falsely negative if the patient is under PPI or bismuth compound treatment or was exposed to antibiotic therapy within the month before testing. The molecular assay on stools should be preferred to evaluate $H$. pylori antibiotic resistance pattern when locally available.

If endoscopy is not required, the use of the stool antigen test or UBT is also recommended to ascertain eradication. For asymptomatic subjects who desire to be evaluated for H. pylori infection, we apply the same strategy.

In the case of a positive family history of gastric malignancy in successfully eradicated dyspeptic patients or asymptomatic subjects, after around six months we perform an upper endoscopy with multiple biopsies (at least 2 from the antrum, 2 from the angulus and 2 from the corpus), in order to assess the presence and the extent of precursor lesions of intestinal type gastric cancer, and to offer, accordingly, the best surveillance program [124].

For patients in whom an upper endoscopy is required, where available, advanced endoscopy techniques (for example NBI, BLI, LCI, etc.) should be preferred to conventional WLE endoscopy, especially for those patients/subjects with a high pretest probability to harbor premalignant lesions, such as those from countries or subpopulations with a high prevalence of gastric cancer, or individuals with strong familiarity for gastric malignancy, or those patients who need a strict endoscopy surveillance for previously diagnosed premalignant lesions.

High-definition endoscopy allows, in real time, the diagnosis of $H$. pylori infection, detection of premalignant and malignant gastric lesions and targeted mucosa biopsy sampling.

Gastric biopsy specimens obtained by high-definition or conventional endoscopy can be used for molecular testing to assess the presence of $H$. pylori and its antibiotic susceptibility profile in patients who are also under PPI treatment. This is particularly useful for those patients who cannot stop the PPI treatment (for instance because of on double antiplatelet treatments, or with a Zollinger Ellison syndrome or similar circumstances).

A RUT and culture would be a good option to detect $H$. pylori and to evaluate the antibiotic resistance profile, however they may result falsely negative in patients exposed to PPI/bismuth/antibiotic. Moreover, they do not allow for the evaluation of the gastric mucosa status.

Under specific conditions, despite the need of an upper endoscopy, it is mandatory to evaluate the risks and benefits to perform an invasive procedure to assess the presence of $H$. pylori infection and/or its sequalae. For instance, in very old or fragile patients, or in those with severe comorbidity, or healthy subjects from regions at low gastric cancer prevalence, but with gastric cancer familiarity, who refuse upper endoscopy, an evaluation with the GastroPanel ${ }^{\circledR}$ may offer a comprehensive overview of the H. pylori and gastric mucosa status.

However, since the GastroPanel ${ }^{\circledR}$ is rarely provided by the public health system, in this setting to test $H$. pylori status in the serum, plasma, saliva, blood or urine (based on what is locally available) may be an option. Evaluation of gastrin and PG I and PG II levels can supply a sort of home-made GastroPanel.

Serology testing does not have the ability to distinguish active from past infection. In addition, the positive predictive value of antibody testing is affected by the local prevalence of $H$. pylori, especially in those areas where the prevalence is inferior to $20 \%$. Although some authors have suggested that quantitative serologic testing may be useful in documenting the infection clearance, this is not usually performed in clinical practice.

Author Contributions: Conceptualization, M.P.D. and G.M.P.; resources, M.P.D. and G.M.P.; data curation, M.P.D. and G.M.P.; writing—original draft preparation, M.P.D. and G.M.P.; writing—review and editing, M.P.D. and G.M.P. All authors have read and agreed to the published version of the manuscript.

Funding: This research received no external funding.

Institutional Review Board Statement: Not applicable. 
Informed Consent Statement: Not applicable.

Conflicts of Interest: The authors declare no conflict of interest.

\section{References}

1. Talley, N.J. American Gastroenterological Association medical position statement: Evaluation of dyspepsia. Gastroenterology 2005, 129, 1753-1755. [CrossRef]

2. Malfertheiner, P.; Megraud, F.; O’Morain, C.; Bazzoli, F.; El-Omar, E.; Graham, D.; Hunt, R.; Rokkas, T.; Vakil, N.; Kuipers, E.J Current concepts in the management of Helicobacter pylori infection: The Maastricht III Consensus Report. Gut 2007, 56, 772-781. [CrossRef] [PubMed]

3. Moayyedi, P.; Lacy, B.E.; Andrews, C.N.; Enns, R.A.; Howden, C.W.; Vakil, N. ACG and CAG Clinical Guideline: Management of Dyspepsia. Am. J. Gastroenterol. 2017, 112, 988-1013. [CrossRef] [PubMed]

4. $\quad$ El-Serag, H.B.; Kao, J.Y.; Kanwal, F.; Gilger, M.; LoVecchio, F.; Moss, S.F.; Crowe, S.E.; Elfant, A.; Haas, T.; Hapke, R.J.; et al. Houston Consensus Conference on Testing for Helicobacter pylori Infection in the United States. Clin. Gastroenterol. Hepatol. 2018, 16, 992-1002.e6. [CrossRef] [PubMed]

5. Dore, M.P.; Pes, G.M.; Bassotti, G.; Usai-Satta, P. Dyspepsia: When and How to Test for Helicobacter pylori Infection. Gastroenterol. Res. Pract. 2016, 2016, 8463614. [CrossRef] [PubMed]

6. Loffeld, R.J. Diagnostic value of endoscopic signs of gastritis: With special emphasis to nodular antritis. Neth. J. Med. 1999, 54, 96-100. [CrossRef]

7. Conti-Nibali, S.; Sferlazzas, C.; Fera, M.T.; Saitta, G.; Tedeschi, A.; Magazzu, G. Helicobacter pylori infection: A simplified diagnostic approach. Am. J. Gastroenterol. 1990, 85, 1573-1575. [PubMed]

8. Luzza, F.; Pensabene, L.; Imeneo, M.; Mancuso, M.; Contaldo, A.; Giancotti, L.; La Vecchia, A.M.; Costa, M.C.; Strisciuglio, P.; Docimo, C.; et al. Antral nodularity identifies children infected with Helicobacter pylori with higher grades of gastric inflammation. Gastrointest. Endosc. 2001, 53, 60-64. [CrossRef] [PubMed]

9. Bah, A.; Saraga, E.; Armstrong, D.; Vouillamoz, D.; Dorta, G.; Duroux, P.; Weber, B.; Froehlich, F.; Blum, A.L.; Schnegg, J.F. Endoscopic features of Helicobacter pylori-related gastritis. Endoscopy 1995, 27, 593-596. [CrossRef]

10. Laine, L.; Cohen, H.; Sloane, R.; Marin-Sorensen, M.; Weinstein, W.M. Interobserver agreement and predictive value of endoscopic findings for H. pylori and gastritis in normal volunteers. Gastrointest. Endosc. 1995, 42, 420-423. [CrossRef]

11. Matrakool, L.; Tongtawee, T.; Bartpho, T.; Dechsukhum, C.; Loyd, R.A.; Kaewpitoon, S.J.; Kaewpitoon, N. Improved Detection of Helicobacter pylori Infection and Premalignant Gastric Mucosa Using Conventional White Light Source Gastroscopy. Asian Pac. J. Cancer Prev. 2016, 17, 2099-2103. [CrossRef] [PubMed]

12. Redeen, S.; Petersson, F.; Jonsson, K.A.; Borch, K. Relationship of gastroscopic features to histological findings in gastritis and Helicobacter pylori infection in a general population sample. Endoscopy 2003, 35, 946-950. [CrossRef] [PubMed]

13. Hatano, Y.; Haruma, K.; Kamada, T.; Shiotani, A.; Takahari, K.; Matsumoto, M.; Uchida, O. Factors Associated with Gastric Black Spot, White Flat Elevated Mucosa, and Cobblestone-Like Mucosa: A Cross-Sectional Study. Digestion 2018, 98, 185-193. [CrossRef]

14. Okamura, T.; Iwaya, Y.; Kitahara, K.; Suga, T.; Tanaka, E. Accuracy of Endoscopic Diagnosis for Mild Atrophic Gastritis Infected with Helicobacter pylori. Clin. Endosc. 2018, 51, 362-367. [CrossRef]

15. Tongtawee, T.; Kaewpitoon, S.; Kaewpitoon, N.; Dechsukhum, C.; Loyd, R.A.; Matrakool, L. Correlation between Gastric Mucosal Morphologic Patterns and Histopathological Severity of Helicobacter pylori Associated Gastritis Using Conventional Narrow Band Imaging Gastroscopy. Biomed. Res. Int. 2015, 2015, 808505. [CrossRef]

16. Tahara, T.; Tahara, S.; Tuskamoto, T.; Horiguchi, N.; Yoshida, D.; Kawamura, T.; Okubo, M.; Nagasaka, M.; Nakagawa, Y.; Urano, M.; et al. Magnifying NBI Patterns of Gastric Mucosa After Helicobacter pylori Eradication and Its Potential Link to the Gastric Cancer Risk. Dig. Dis. Sci. 2017, 62, 2421-2427. [CrossRef]

17. Kanemitsu, T.; Yao, K.; Nagahama, T.; Imamura, K.; Fujiwara, S.; Ueki, T.; Chuman, K.; Tanabe, H.; Atsuko, O.; Iwashita, A.; et al. Extending magnifying NBI diagnosis of intestinal metaplasia in the stomach: The white opaque substance marker. Endoscopy 2017, 49, 529-535. [CrossRef]

18. White, J.R.; Sami, S.S.; Reddiar, D.; Mannath, J.; Ortiz-Fernandez-Sordo, J.; Beg, S.; Scott, R.; Thiagarajan, P.; Ahmad, S.; ParraBlanco, A.; et al. Narrow band imaging and serology in the assessment of premalignant gastric pathology. Scand. J. Gastroenterol. 2018, 53, 1611-1618. [CrossRef]

19. Rugge, M.; Kim, J.G.; Mahachai, V.; Miehlke, S.; Pennelli, G.; Russo, V.M.; Perng, C.L.; Chang, F.Y.; Tandon, R.K.; Singal, D.K.; et al. OLGA gastritis staging in young adults and country-specific gastric cancer risk. Int. J. Surg. Pathol. 2008, 16, 150-154. [CrossRef]

20. Saka, A.; Yagi, K.; Nimura, S. OLGA- and OLGIM-based staging of gastritis using narrow-band imaging magnifying endoscopy. Dig. Endosc. 2015, 27, 734-741. [CrossRef]

21. Kotachi, T.; Ito, M.; Boda, T.; Kiso, M.; Masuda, K.; Hata, K.; Kawamura, T.; Sanomura, Y.; Yoshihara, M.; Tanaka, S.; et al. Clinical Significance of Reddish Depressed Lesions Observed in the Gastric Mucosa after Helicobacter pylori Eradication. Digestion 2018, 98, 48-55. [CrossRef] [PubMed]

22. Horiguchi, N.; Tahara, T.; Kawamura, T.; Okubo, M.; Tahara, S.; Nagasaka, M.; Nakagawa, Y.; Shibata, T.; Ohmiya, N. A Comparative Study of White Light Endoscopy, Chromoendoscopy and Magnifying Endoscopy with Narrow Band Imaging in the Diagnosis of Early Gastric Cancer after Helicobacter pylori Eradication. J. Gastrointestin. Liver Dis. 2017, 26, 357-362. [CrossRef] 
23. Horiguchi, N.; Tahara, T.; Yamada, H.; Yoshida, D.; Okubo, M.; Nagasaka, M.; Nakagawa, Y.; Shibata, T.; Tsukamoto, T.; Kuroda, M.; et al. In vivo diagnosis of early-stage gastric cancer found after Helicobacter pylori eradication using probe-based confocal laser endomicroscopy. Dig. Endosc. 2018, 30, 219-227. [CrossRef]

24. Nishikawa, Y.; Ikeda, Y.; Murakami, H.; Hori, S.I.; Hino, K.; Sasaki, C.; Nishikawa, M. Classification of atrophic mucosal patterns on Blue LASER Imaging for endoscopic diagnosis of Helicobacter pylori-related gastritis: A retrospective, observational study. PLoS ONE 2018, 13, e0193197. [CrossRef] [PubMed]

25. Osawa, H.; Miura, Y.; Takezawa, T.; Ino, Y.; Khurelbaatar, T.; Sagara, Y.; Lefor, A.K.; Yamamoto, H. Linked Color Imaging and Blue Laser Imaging for Upper Gastrointestinal Screening. Clin. Endosc. 2018, 51, 513-526. [CrossRef]

26. Jiang, Z.X.; Nong, B.; Liang, L.X.; Yan, Y.D.; Zhang, G. Differential diagnosis of Helicobacter pylori-associated gastritis with the linked-color imaging score. Dig. Liver Dis. 2019, 51, 1665-1670. [CrossRef] [PubMed]

27. Ono, S.; Dohi, O.; Yagi, N.; Sanomura, Y.; Tanaka, S.; Naito, Y.; Sakamoto, N.; Kato, M. Accuracies of Endoscopic Diagnosis of Helicobacter pylori-Gastritis: Multicenter Prospective Study Using White Light Imaging and Linked Color Imaging. Digestion 2020, 101, 624-630. [CrossRef] [PubMed]

28. Wang, L.; Lin, X.C.; Li, H.L.; Yang, X.S.; Zhang, L.; Li, X.; Bai, P.; Wang, Y.; Fan, X.; Ding, Y.M. Clinical significance and influencing factors of linked color imaging technique in real-time diagnosis of active Helicobacter pylori infection. Chin. Med. J. Engl. 2019, 132, 2395-2401. [CrossRef]

29. Zhu, Y.; Wang, F.; Zhou, Y.; Xia, G.L.; Dong, L.; He, W.H.; Xiao, B. Blue laser magnifying endoscopy in the diagnosis of chronic gastritis. Exp. Ther. Med. 2019, 18, 1993-2000. [CrossRef]

30. Sato, H.; Inoue, H.; Ikeda, H.; Sato, C.; Phlanusittepha, C.; Hayee, B.; Santi, E.G.; Kobayashi, Y.; Kudo, S.E. In vivo gastric mucosal histopathology using endocytoscopy. World J. Gastroenterol. 2015, 21, 5002-5008. [CrossRef]

31. Fontenete, S.; Leite, M.; Figueiredo, C.; Cos, P.; Azevedo, N.F. Detection of Helicobacter pylori in the Gastric Mucosa by Fluorescence In Vivo Hybridization. Methods Mol. Biol. 2017, 1616, 137-146. [CrossRef] [PubMed]

32. Toyoshima, O.; Nishizawa, T.; Koike, K. Endoscopic Kyoto classification of Helicobacter pylori infection and gastric cancer risk diagnosis. World J. Gastroenterol. 2020, 26, 466-477. [CrossRef]

33. Nakashima, H.; Kawahira, H.; Kawachi, H.; Sakaki, N. Artificial intelligence diagnosis of Helicobacter pylori infection using blue laser imaging-bright and linked color imaging: A single-center prospective study. Ann. Gastroenterol. 2018, 31, 462-468. [CrossRef]

34. Bang, C.S.; Lee, J.J.; Baik, G.H. Artificial Intelligence for the Prediction of Helicobacter pylori Infection in Endoscopic Images: Systematic Review and Meta-Analysis Of Diagnostic Test Accuracy. J. Med. Internet Res. 2020, 22, e21983. [CrossRef]

35. Dixon, M.F.; Genta, R.M.; Yardley, J.H.; Correa, P. Classification and grading of gastritis. The updated Sydney System. International Workshop on the Histopathology of Gastritis, Houston 1994. Am. J. Surg. Pathol. 1996, 20, 1161-1181. [CrossRef] [PubMed]

36. Varbanova, M.; Wex, T.; Jechorek, D.; Rohl, F.W.; Langner, C.; Selgrad, M.; Malfertheiner, P. Impact of the angulus biopsy for the detection of gastric preneoplastic conditions and gastric cancer risk assessment. J. Clin. Pathol. 2016, 69, 19-25. [CrossRef] [PubMed]

37. Graham, D.Y.; Opekun, A.R.; Yamaoka, Y.; Osato, M.S.; el-Zimaity, H.M. Early events in proton pump inhibitor-associated exacerbation of corpus gastritis. Aliment. Pharmacol. Ther. 2003, 17, 193-200. [CrossRef] [PubMed]

38. Glickman, J.N.; Noffsinger, A.; Nevin, D.T.; Ray, M.; Lash, R.H.; Genta, R.M. Helicobacter infections with rare bacteria or minimal gastritis: Expecting the unexpected. Dig. Liver Dis. 2015, 47, 549-555. [CrossRef] [PubMed]

39. Snead, D.R.; Tsang, Y.W.; Meskiri, A.; Kimani, P.K.; Crossman, R.; Rajpoot, N.M.; Blessing, E.; Chen, K.; Gopalakrishnan, K.; Matthews, P.; et al. Validation of digital pathology imaging for primary histopathological diagnosis. Histopathology 2016, 68, 1063-1072. [CrossRef] [PubMed]

40. Benoit, A.; Hoyeau, N.; Flejou, J.F. Diagnosis of Helicobacter pylori infection on gastric biopsies: Standard stain, special stain or immunohistochemistry? Ann. Pathol. 2018, 38, 363-369. [CrossRef]

41. Godbole, G.; Megraud, F.; Bessede, E. Review: Diagnosis of Helicobacter pylori infection. Helicobacter 2020, 25 (Suppl. 1), e12735. [CrossRef]

42. Seo, J.H.; Park, J.S.; Rhee, K.H.; Youn, H.S. Limitations of urease test in diagnosis of pediatric Helicobacter pylori infection. World J. Clin. Pediatr. 2015, 4, 143-147. [CrossRef] [PubMed]

43. Cho, J.H.; Jeon, S.R.; Kim, H.G.; Jin, S.Y.; Park, S. Factors for improving the diagnostic efficiency of the rapid urease test from the gastric corpus. Scand. J. Gastroenterol. 2017, 52, 1320-1325. [CrossRef] [PubMed]

44. Parihar, V.; Holleran, G.; Hall, B.; Brennan, D.; Crotty, P.; McNamara, D. A combined antral and corpus rapid urease testing protocol can increase diagnostic accuracy despite a low prevalence of Helicobacter pylori infection in patients undergoing routine gastroscopy. United Eur. Gastroenterol. J. 2015, 3, 432-436. [CrossRef] [PubMed]

45. Dechant, F.X.; Dechant, R.; Kandulski, A.; Selgrad, M.; Weber, F.; Reischl, U.; Wilczek, W.; Mueller, M.; Weigand, K. Accuracy of Different Rapid Urease Tests in Comparison with Histopathology in Patients with Endoscopic Signs of Gastritis. Digestion 2020, 101, 184-190. [CrossRef] [PubMed]

46. Dolak, W.; Bilgilier, C.; Stadlmann, A.; Leiner, J.; Puspok, A.; Plieschnegger, W.; Siebert, F.; Wewalka, F.; Schofl, R.; HuberSchonauer, U.; et al. A multicenter prospective study on the diagnostic performance of a new liquid rapid urease test for the diagnosis of Helicobacter pylori infection. Gut Pathog. 2017, 9, 78. [CrossRef] [PubMed]

47. Kuhns, L.G.; Benoit, S.L.; Bayyareddy, K.; Johnson, D.; Orlando, R.; Evans, A.L.; Waldrop, G.L.; Maier, R.J. Carbon Fixation Driven by Molecular Hydrogen Results in Chemolithoautotrophically Enhanced Growth of Helicobacter pylori. J. Bacteriol. 2016, 198, 1423-1428. [CrossRef] 
48. Peretz, A.; On, A.; Koifman, A.; Brodsky, D.; Isakovich, N.; Glyatman, T.; Paritsky, M. An efficiency comparison between three invasive methods for the diagnosis of Helicobacter pylori infections: Culture from stomach biopsy, rapid urease test (CUTest((R))), and histologic examination of gastric biopsy. Ann. Clin. Lab. Sci. 2015, 45, 148-151.

49. Peretz, A.; Paritsky, M.; Pastukh, N.; Koifman, A.; Brodsky, D.; Glyatman, T.; On, A. Improvement and optimization of the classical gastric biopsy culture technique for Helicobacter pylori diagnosis using trypsin. J. Med. Microbiol. 2015, 64, 642-645. [CrossRef]

50. Pohl, D.; Keller, P.M.; Bordier, V.; Wagner, K. Review of current diagnostic methods and advances in Helicobacter pylori diagnostics in the era of next generation sequencing. World J. Gastroenterol. 2019, 25, 4629-4660. [CrossRef] [PubMed]

51. Yin, S.M.; Zhang, F.; Shi, D.M.; Xiang, P.; Xiao, L.; Huang, Y.Q.; Zhang, G.S.; Bao, Z.J. Effect of posture on (13)C-urea breath test in partial gastrectomy patients. World J. Gastroenterol. 2015, 21, 12888-12895. [CrossRef] [PubMed]

52. Klein, P.D.; Malaty, H.M.; Martin, R.F.; Graham, K.S.; Genta, R.M.; Graham, D.Y. Noninvasive detection of Helicobacter pylori infection in clinical practice: The 13C urea breath test. Am. J. Gastroenterol. 1996, 91, 690-694. [PubMed]

53. Best, L.M.; Takwoingi, Y.; Siddique, S.; Selladurai, A.; Gandhi, A.; Low, B.; Yaghoobi, M.; Gurusamy, K.S. Non-invasive diagnostic tests for Helicobacter pylori infection. Cochrane Database Syst. Rev. 2018, 3, CD012080. [CrossRef]

54. Abd Rahim, M.A.; Johani, F.H.; Shah, S.A.; Hassan, M.R.; Abdul Manaf, M.R. ${ }^{13}$ C-Urea Breath Test Accuracy for Helicobacter pylori Infection in the Asian Population: A Meta-Analysis. Ann. Glob. Health 2019, 85. [CrossRef]

55. Coelho, L.G.; Sant'Ana, C.R.; Oliveira, R.B.; Cezar, R.C.E.; Araujo, A.C.C.; Silva, R.; Trindade, O.R.; Coelho, M.C.; Ferrioli, E.; Bendassolli, J.A. Performance of the 13C-urea breath test for the diagnosis of H. pylori infection using a substrate synthesized in Brazil: A preliminary study. Clin. Sao Paulo 2018, 73, e16553. [CrossRef]

56. Agha, A.; Opekun, A.R.; Abudayyeh, S.; Graham, D.Y. Effect of different organic acids (citric, malic and ascorbic) on intragastric urease activity. Aliment. Pharmacol. Ther. 2005, 21, 1145-1148. [CrossRef]

57. Tepes, B.; Seruga, M.; Vujasinovic, M.; Urlep, D.; Ljepovic, L.; Brglez, J.N.; Forte, A.; Anita Kek, L.; Skvarc, M. Premalignant Gastric Lesions in Patients Included in National Colorectal Cancer Screening. Radiol. Oncol. 2018, 52, 7-13. [CrossRef] [PubMed]

58. Eisdorfer, I.; Shalev, V.; Goren, S.; Chodick, G.; Muhsen, K. Sex differences in urea breath test results for the diagnosis of Helicobacter pylori infection: A large cross-sectional study. Biol. Sex Differ. 2018, 9, 1. [CrossRef] [PubMed]

59. Kwon, Y.H.; Kim, N.; Lee, J.Y.; Choi, Y.J.; Yoon, K.; Hwang, J.J.; Lee, H.J.; Lee, A.; Jeong, Y.S.; Oh, S.; et al. The Diagnostic Validity of Citric Acid-Free, High Dose (13)C-Urea Breath Test After Helicobacter pylori Eradication in Korea. Helicobacter 2015, 20, 159-168. [CrossRef] [PubMed]

60. Suki, M.; Leibovici Weissman, Y.; Boltin, D.; Itskoviz, D.; Tsadok Perets, T.; Comaneshter, D.; Cohen, A.; Niv, Y.; Dotan, I.; Leibovitzh, H.; et al. Helicobacter pylori infection is positively associated with an increased BMI, irrespective of socioeconomic status and other confounders: A cohort study. Eur. J. Gastroenterol. Hepatol. 2018, 30, 143-148. [CrossRef]

61. Graham, D.Y.; Miftahussurur, M. Helicobacter pylori urease for diagnosis of Helicobacter pylori infection: A mini review. J. Adv. Res. 2018, 13, 51-57. [CrossRef] [PubMed]

62. Li, Z.X.; Huang, L.L.; Liu, C.; Formichella, L.; Zhang, Y.; Wang, Y.M.; Zhang, L.; Ma, J.L.; Liu, W.D.; Ulm, K.; et al. Cut-off optimization for (13)C-urea breath test in a community-based trial by mathematic, histology and serology approach. Sci. Rep. 2017, 7, 2072. [CrossRef] [PubMed]

63. Perets, T.T.; Gingold-Belfer, R.; Leibovitzh, H.; Itskoviz, D.; Schmilovitz-Weiss, H.; Snir, Y.; Dickman, R.; Dotan, I.; Levi, Z.; Boltin, D. Optimization of (13) C-urea breath test threshold levels for the detection of Helicobacter pylori infection in a national referral laboratory. J. Clin. Lab. Anal. 2019, 33, e22674. [CrossRef]

64. Unler, G.K.; Ozgur, G.T.; Gokturk, H.S.; Durukan, E.; Erhamamci, S. Does the urea breath test predict eradication of Helicobacter pylori infection? Acta Gastroenterol. Belg. 2016, 79, 3-7.

65. Molina-Molina, E.; Bonfrate, L.; Lorusso, M.; Shanmugam, H.; Scaccianoce, G.; Rokkas, T.; Portincasa, P. Faster Detection of Helicobacter pylori Infection by 13 C-Urea Breath Test. Comparing Short versus Standard Sampling Time. J. Gastrointestin. Liver Dis. 2019, 28, 151-161. [CrossRef]

66. Richter, V.; Gonzalez, J.O.; Hazan, S.; Gottlieb, G.; Friedenberg, K.; Gatof, D.; Ganeshappa, R.; Delgado, J.S.; Abramowitz, D.; Hardi, R.; et al. The validity of breath collection bags method in detecting Helicobacter pylori using the novel BreathID ((R)) Hp Lab System: A multicenter clinical study in 257 subjects. Ther. Adv. Gastrointest. Endosc. 2019, 12, 2631774519843401. [CrossRef]

67. Coelho, L.G.V.; Trindade, O.R.; Leao, L.A.; Ribeiro, H.G.; Freitas, I.S.; Coelho, M.C.F. Prospective Study for Validation of a Single Protocol for the 13c-Urea Breath Test Using Two Different Devices in the Diagnosis of H. Pylori Infection. Arq. Gastroenterol. 2019, 56, 197-201. [CrossRef]

68. Opekun, A.R.; Abdalla, N.; Sutton, F.M.; Hammoud, F.; Kuo, G.M.; Torres, E.; Steinbauer, J.; Graham, D.Y. Urea breath testing and analysis in the primary care office. J. Fam. Pract. 2002, 51, 1030-1032.

69. Kwon, Y.H.; Kim, N.; Yoon, H.; Shin, C.M.; Park, Y.S.; Lee, D.H. Effect of Citric Acid on Accuracy of (13)C-Urea Breath Test after Helicobacter pylori Eradication Therapy in a Region with a High Prevalence of Atrophic Gastritis. Gut Liver 2019, 13, 506-514. [CrossRef]

70. Ramirez-Lazaro, M.J.; Lite, J.; Lario, S.; Perez-Jove, P.; Montserrat, A.; Quilez, M.E.; Martinez-Bauer, E.; Calvet, X. Good diagnostic accuracy of a chemiluminescent immunoassay in stool samples for diagnosis of Helicobacter pylori infection in patients with dyspepsia. J. Investig. Med. 2016, 64, 388-391. [CrossRef]

71. Dore, M.P.; Osato, M.S.; Malaty, H.M.; Graham, D.Y. Characterization of a culture method to recover Helicobacter pylori from the feces of infected patients. Helicobacter 2000, 5, 165-168. [CrossRef] [PubMed] 
72. Malfertheiner, P.; Megraud, F.; O’Morain, C.A.; Gisbert, J.P.; Kuipers, E.J.; Axon, A.T.; Bazzoli, F.; Gasbarrini, A.; Atherton, J.; Graham, D.Y.; et al. Management of Helicobacter pylori infection-the Maastricht V/Florence Consensus Report. Gut 2017, 66, 6-30. [CrossRef]

73. Vaira, D.; Malfertheiner, P.; Megraud, F.; Axon, A.T.; Deltenre, M.; Hirschl, A.M.; Gasbarrini, G.; O’Morain, C.; Garcia, J.M.; Quina, M.; et al. Diagnosis of Helicobacter pylori infection with a new non-invasive antigen-based assay. HpSA European study group. Lancet 1999, 354, 30-33. [CrossRef]

74. Korkmaz, H.; Findik, D.; Ugurluoglu, C.; Terzi, Y. Reliability of stool antigen tests: Investigation of the diagnostic value of a new immunochromatographic Helicobacter pylori approach in dyspeptic patients. Asian Pac. J. Cancer Prev. 2015, 16, 657-660. [CrossRef] [PubMed]

75. Lario, S.; Ramirez-Lazaro, M.J.; Montserrat, A.; Quilez, M.E.; Junquera, F.; Martinez-Bauer, E.; Sanfeliu, I.; Brullet, E.; Campo, R.; Segura, F.; et al. Diagnostic accuracy of three monoclonal stool tests in a large series of untreated Helicobacter pylori infected patients. Clin. Biochem. 2016, 49, 682-687. [CrossRef]

76. Moubri, M.; Burucoa, C.; Kalach, N.; Larras, R.R.; Nouar, N.; Mouffok, F.; Arrada, Z. Performances of the IDEIA HpStAR Stool Antigen Test in Detection of Helicobacter pylori Infection Before and After Eradication Treatment in Algerian Children. J. Trop Pediatr. 2019, 65, 210-216. [CrossRef]

77. Kakiuchi, T.; Okuda, M.; Hashiguchi, K.; Imamura, I.; Nakayama, A.; Matsuo, M. Evaluation of a Novel Stool Antigen Rapid Test Kit for Detection of Helicobacter pylori Infection. J. Clin. Microbiol. 2019, 57. [CrossRef]

78. Fang, Y.J.; Chen, M.J.; Chen, C.C.; Lee, J.Y.; Yang, T.H.; Yu, C.C.; Chiu, M.C.; Kuo, C.C.; Weng, Y.J.; Bair, M.J.; et al. Accuracy of rapid Helicobacter pylori antigen tests for the surveillance of the updated prevalence of H. pylori in Taiwan. J. Formos Med. Assoc. 2020, 119, 1626-1633. [CrossRef]

79. Dore, M.P.; Negrini, R.; Tadeu, V.; Marras, L.; Maragkoudakis, E.; Nieddu, S.; Simula, L.; Cherchi, G.B.; Massarelli, G.; Realdi, G. Novel monoclonal antibody-based Helicobacter pylori stool antigen test. Helicobacter 2004, 9, 228-232. [CrossRef] [PubMed]

80. Gisbert, J.P.; de la Morena, F.; Abraira, V. Accuracy of monoclonal stool antigen test for the diagnosis of H. pylori infection: A systematic review and meta-analysis. Am. J. Gastroenterol. 2006, 101, 1921-1930. [CrossRef] [PubMed]

81. Guarner, J.; Kalach, N.; Elitsur, Y.; Koletzko, S. Helicobacter pylori diagnostic tests in children: Review of the literature from 1999 to 2009. Eur. J. Pediatr. 2010, 169, 15-25. [CrossRef]

82. Bénéjat, L.; Ducournau, A.; Lehours, P.; Megraud, F. Real-time PCR for Helicobacter pylori diagnosis. The best tools available. Helicobacter 2018, 23, e12512. [CrossRef]

83. Redondo, J.J.; Keller, P.M.; Zbinden, R.; Wagner, K. A novel RT-PCR for the detection of Helicobacter pylori and identification of clarithromycin resistance mediated by mutations in the 23S rRNA gene. Diagn Microbiol. Infect Dis. 2018, 90, 1-6. [CrossRef] [PubMed]

84. Talarico, S.; Safaeian, M.; Gonzalez, P.; Hildesheim, A.; Herrero, R.; Porras, C.; Cortes, B.; Larson, A.; Fang, F.C.; Salama, N.R. Quantitative Detection and Genotyping of Helicobacter pylori from Stool using Droplet Digital PCR Reveals Variation in Bacterial Loads that Correlates with cagA Virulence Gene Carriage. Helicobacter 2016, 21, 325-333. [CrossRef]

85. Bazin, T.; Nchare Mfondi, A.; Julie, C.; Emile, J.F.; Raymond, J.; Lamarque, D. Contribution of genetic amplification by PCR for the diagnosis of Helicobacter pylori infection in patients receiving proton pump inhibitors. United Eur. Gastroenterol. J. 2018, 6, 1267-1273. [CrossRef]

86. Morilla, A.; Melon, S.; Alvarez-Arguelles, M.E.; Armesto, E.; Villar, H.; de Ona, M. Utility of normalized genome quantification of Helicobacter pylori in gastric mucosa using an in-house real-time polymerase chain reaction. PLoS ONE 2017, 12, e0178674. [CrossRef] [PubMed]

87. Kalach, N.; Gosset, P.; Dehecq, E.; Decoster, A.; Spyckerelle, C.; Papadopolos, S.; Dupont, C.; Raymond, J. Usefulness of Gastric Biopsy-Based Real-Time Polymerase Chain Reaction for the Diagnosis of Helicobacter pylori Infection in Children. J. Pediatr. Gastroenterol. Nutr. 2015, 61, 307-312. [CrossRef]

88. Matsumoto, H.; Shiotani, A.; Nishibayashi, H.; Kamada, T.; Kimura, T.; Fujimura, Y.; Nakato, R.; Murao, T.; Fujita, M.; Haruma, K. Molecular Detection of H. pylori Using Adherent Gastric Mucous to Biopsy Forceps. Helicobacter 2016, 21, 548-553. [CrossRef]

89. Chung, W.C.; Jeon, E.J.; Oh, J.H.; Park, J.M.; Kim, T.H.; Cheung, D.Y.; Kim, B.W.; Kim, S.S.; Kim, J.I. Dual-priming oligonucleotidebased multiplex PCR using tissue samples from the rapid urease test kit for the detection of Helicobacter pylori in bleeding peptic ulcers. Dig. Liver Dis. 2016, 48, 899-903. [CrossRef]

90. Hsieh, M.S.; Liu, C.J.; Hsu, W.H.; Li, C.J.; Tsai, P.Y.; Hu, H.M.; Shih, H.Y.; Lu, C.Y.; Yu, F.J.; Kuo, F.C.; et al. Gastric juice-based PCR assay: An alternative testing method to aid in the management of previously treated Helicobacter pylori infection. Helicobacter 2019, 24, e12568. [CrossRef] [PubMed]

91. Peng, X.; Song, Z.; He, L.; Lin, S.; Gong, Y.; Sun, L.; Zhao, F.; Gu, Y.; You, Y.; Zhou, L.; et al. Gastric Juice-Based Real-Time PCR for Tailored Helicobacter pylori Treatment: A Practical Approach. Int. J. Med. Sci. 2017, 14, 595-601. [CrossRef] [PubMed]

92. Piroozmand, A.; Soltani, B.; Razavizadeh, M.; Matini, A.H.; Moosavi, G.A.; Salehi, M.; Soltani, S. Comparison of gastric juice soluble triggering receptor expressed on myeloid cells and C-reactive protein for detection of Helicobacter pylori infection. Electron. Physician 2017, 9, 6111-6119. [CrossRef] [PubMed]

93. Talarico, S.; Korson, A.S.; Leverich, C.K.; Park, S.; Jalikis, F.G.; Upton, M.P.; Broussard, E.; Salama, N.R. High prevalence of Helicobacter pylori clarithromycin resistance mutations among Seattle patients measured by droplet digital PCR. Helicobacter 2018, 23, e12472. [CrossRef] [PubMed] 
94. Nezami, B.G.; Jani, M.; Alouani, D.; Rhoads, D.D.; Sadri, N. Helicobacter pylori Mutations Detected by Next-Generation Sequencing in Formalin-Fixed, Paraffin-Embedded Gastric Biopsy Specimens Are Associated with Treatment Failure. J. Clin. Microbiol. 2019, 57. [CrossRef]

95. Zhou, L.; Zhao, F.; Hu, B.; Fang, Y.; Miao, Y.; Huang, Y.; Ji, D.; Zhang, J.; Xu, L.; Zhang, Y.; et al. A Creative Helicobacter pylori Diagnosis Scheme Based on Multiple Genetic Analysis System: Qualification and Quantitation. Helicobacter 2015, 20, 343-352. [CrossRef]

96. Trespalacios, A.A.; Rimbara, E.; Otero, W.; Reddy, R.; Graham, D.Y. Improved allele-specific PCR assays for detection of clarithromycin and fluoroquinolone resistant of Helicobacter pylori in gastric biopsies: Identification of N87I mutation in GyrA. Diagn. Microbiol. Infect. Dis. 2015, 81, 251-255. [CrossRef] [PubMed]

97. Yari, F.; Abiri, R.; Aryan, E.; Ahmadi Jouybari, T.; Navabi, J.; Alvandi, A. Loop-Mediated Isothermal Amplification as a Fast Noninvasive Method of Helicobacter pylori Diagnosis. J. Clin. Lab. Anal. 2016, 30, 464-470. [CrossRef] [PubMed]

98. Beckman, E.; Saracino, I.; Fiorini, G.; Clark, C.; Slepnev, V.; Patel, D.; Gomez, C.; Ponaka, R.; Elagin, V.; Vaira, D. A Novel Stool PCR Test for Helicobacter pylori May Predict Clarithromycin Resistance and Eradication of Infection at a High Rate. J. Clin. Microbiol. 2017, 55, 2400-2405. [CrossRef]

99. Iannone, A.; Giorgio, F.; Russo, F.; Riezzo, G.; Girardi, B.; Pricci, M.; Palmer, S.C.; Barone, M.; Principi, M.; Strippoli, G.F.; et al. New fecal test for non-invasive Helicobacter pylori detection: A diagnostic accuracy study. World J. Gastroenterol. 2018, 24, 3021-3029. [CrossRef]

100. Clines, N.; Beckman, E. Development of a high throughput human stool specimen processing method for a molecular Helicobacter pylori clarithromycin resistance assay. PLoS ONE 2019, 14, e0224356. [CrossRef]

101. Pichon, M.; Pichard, B.; Barrioz, T.; Plouzeau, C.; Croquet, V.; Fotsing, G.; Cheron, A.; Vuillemin, E.; Wangermez, M.; Haineaux, P.A.; et al. Diagnostic Accuracy of a Noninvasive Test for Detection of Helicobacter pylori and Resistance to Clarithromycin in Stool by the Amplidiag H. pylori+ClariR Real-Time PCR Assay. J. Clin. Microbiol. 2020, 58. [CrossRef] [PubMed]

102. Butt, J.; Blot, W.J.; Shrubsole, M.J.; Varga, M.G.; Hendrix, L.H.; Crankshaw, S.; Waterboer, T.; Pawlita, M.; Epplein, M. Performance of multiplex serology in discriminating active vs past Helicobacter pylori infection in a primarily African American population in the southeastern United States. Helicobacter 2020, 25, e12671. [CrossRef] [PubMed]

103. Shafaie, E.; Saberi, S.; Esmaeili, M.; Karimi, Z.; Najafi, S.; Tashakoripoor, M.; Abdirad, A.; Hosseini, M.E.; Mohagheghi, M.A.; Khalaj, V.; et al. Multiplex serology of Helicobacter pylori antigens in detection of current infection and atrophic gastritis-A simple and cost-efficient method. Microb. Pathog. 2018, 119, 137-144. [CrossRef] [PubMed]

104. Kawai, S.; Arai, K.; Lin, Y.; Nishiyama, T.; Sasakabe, T.; Wang, C.; Miwa, H.; Kikuchi, S. Comparison of the detection of Helicobacter pylori infection by commercially available serological testing kits and the (13)C-urea breath test. J. Infect. Chemother. 2019, 25, 769-773. [CrossRef] [PubMed]

105. Miftahussurur, M.; Yamaoka, Y. Diagnostic Methods of Helicobacter pylori Infection for Epidemiological Studies: Critical Importance of Indirect Test Validation. Biomed. Res. Int. 2016, 2016, 4819423. [CrossRef]

106. Miwa, H.; Kikuchi, S.; Ohtaka, K.; Kobayashi, O.; Ogihara, A.; Hojo, M.; Nagahara, A.; Sato, N. Insufficient diagnostic accuracy of imported serological kits for Helicobacter pylori infection in Japanese population. Diagn. Microbiol. Infect. Dis. 2000, 36, 95-99. [CrossRef]

107. Theel, E.S.; Johnson, R.D.; Plumhoff, E.; Hanson, C.A. Use of the Optum Labs Data Warehouse to assess test ordering patterns for diagnosis of Helicobacter pylori infection in the United States. J. Clin. Microbiol. 2015, 53, 1358-1360. [CrossRef]

108. Toyoshima, O.; Nishizawa, T.; Sakitani, K.; Yamakawa, T.; Takahashi, Y.; Yamamichi, N.; Hata, K.; Seto, Y.; Koike, K.; Watanabe, H.; et al. Serum anti-Helicobacter pylori antibody titer and its association with gastric nodularity, atrophy, and age: A cross-sectional study. World J. Gastroenterol. 2018, 24, 4061-4068. [CrossRef]

109. Epplein, M.; Butt, J.; Zhang, Y.; Hendrix, L.H.; Abnet, C.C.; Murphy, G.; Zheng, W.; Shu, X.O.; Tsugane, S.; Qiao, Y.L.; et al. Validation of a Blood Biomarker for Identification of Individuals at High Risk for Gastric Cancer. Cancer Epidemiol. Biomark. Prev. 2018, 27, 1472-1479. [CrossRef]

110. MÄki, M.; SÖderstrÖm, D.; Paloheimo, L.; Hendolin, P.; Suovaniemi, O.; Syrjänen, K. Helicobacter pylori (Hp) IgG ELISA of the New-Generation GastroPanel(R) Is Highly Accurate in Diagnosis of Hp-Infection in Gastroscopy Referral Patients. Anticancer Res. 2020, 40, 6387-6398. [CrossRef]

111. Lee, S.P.; Lee, S.Y.; Kim, J.H.; Sung, I.K.; Park, H.S.; Shim, C.S. Link between Serum Pepsinogen Concentrations and Upper Gastrointestinal Endoscopic Findings. J. Korean Med. Sci. 2017, 32, 796-802. [CrossRef] [PubMed]

112. Paloheimo, L.; Tiusanen, T.; Suovaniemi, O.; SyrjAnen, K. Serological Biomarker Test (GastroPanel((R))) in the Diagnosis of Functional Gastric Disorders, Helicobacter pylori and Atrophic Gastritis in Patients Examined for Dyspeptic Symptoms. Anticancer Res. 2021, 41, 811-819. [CrossRef] [PubMed]

113. Syrjänen, K.; Eskelinen, M.; Peetsalu, A.; Sillakivi, T.; Sipponen, P.; Harkonen, M.; Paloheimo, L.; Maki, M.; Tiusanen, T.; Suovaniemi, O.; et al. GastroPanel(R) Biomarker Assay: The Most Comprehensive Test for Helicobacter pylori Infection and Its Clinical Sequelae. A Critical Review. Anticancer Res. 2019, 39, 1091-1104. [CrossRef] [PubMed]

114. Sjomina, O.; Pavlova, J.; Daugule, I.; Janovic, P.; Kikuste, I.; Vanags, A.; Tolmanis, I.; Rudzite, D.; Polaka, I.; Kojalo, I.; et al. Pepsinogen test for the evaluation of precancerous changes in gastric mucosa: A population-based study. J. Gastrointestin. Liver Dis. 2018, 27, 11-17. [CrossRef] [PubMed] 
115. Shan, J.; Lei, H.; Shi, W.; Sun, X.; Tang, Y.; Ren, C. High Serum Pepsinogen I and beta Helicobacter pylori Infection Are Risk Factors for Aspirin-Induced Gastroduodenal Injury. Dig. Dis. 2018, 36, 66-71. [CrossRef]

116. Chinda, D.; Shimoyama, T.; Mikami, T.; Arai, T.; Chiba, D.; Sasaki, Y.; Komai, K.; Sawada, Y.; Saito, Y.; Chiba, H.; et al. Serum pepsinogen levels indicate the requirement of upper gastrointestinal endoscopy among Group A subjects of ABC classification: A multicenter study. J. Gastroenterol. 2018, 53, 924-931. [CrossRef]

117. Yu, J.; Xu, Q.; Zhang, X.; Zhu, M. Circulating microRNA signatures serve as potential diagnostic biomarkers for Helicobacter pylori infection. J. Cell Biochem. 2018. [CrossRef] [PubMed]

118. Skrebinska, S.; Daugule, I.; Santare, D.; Isajevs, S.; Liepniece-Karele, I.; Rudzite, D.; Kikuste, I.; Vanags, A.; Tolmanis, I.; Atstupens, J.; et al. Accuracy of two plasma antibody tests and faecal antigen test for non-invasive detection of H. pylori in middle-aged Caucasian general population sample. Scand. J. Gastroenterol. 2018, 53, 777-783. [CrossRef] [PubMed]

119. Kumar, A.; Mhatre, S.; Dikshit, R. Utility of dried blood spots in detecting Helicobacter pylori infection. Indian J. Med. Microbiol. 2019, 37, 514-520. [CrossRef] [PubMed]

120. Okuda, M.; Mabe, K.; Lin, Y.; Chaochen, W.; Taniguchi, Y.; Kato, M.; Kikuchi, S. Rapid urine antibody test for Helicobacter pylori infection in adolescents. Pediatr. Int. 2017, 59, 798-802. [CrossRef] [PubMed]

121. Piroozmand, A.; Soltani, B.; Razavizadeh, M.; Matini, A.H.; Gilasi, H.R.; Zavareh, A.N.; Soltani, S. Comparison of the serum and salivary antibodies to detect gastric Helicobacter pylori infection in Kashan (Iran). Electron. Physician 2017, 9, 6129-6134. [CrossRef]

122. Aumpan, N.; Vilaichone, R.K.; Chotivitayatarakorn, P.; Pornthisarn, B.; Cholprasertsuk, S.; Bhanthumkomol, P.; Kanokwanvimol, A.; Siramolpiwat, S.; Mahachai, V. High Efficacy of Rapid Urine Test for Diagnosis of Helicobacter pylori Infection in Thai People. Asian Pac. J. Cancer Prev. 2019, 20, 1525-1529. [CrossRef] [PubMed]

123. Aksit Bicak, D.; Akyuz, S.; Kiratli, B.; Usta, M.; Urganci, N.; Alev, B.; Yarat, A.; Sahin, F. The investigation of Helicobacter pylori in the dental biofilm and saliva samples of children with dyspeptic complaints. BMC Oral Health 2017, 17, 67. [CrossRef]

124. Dore, M.P.; Cipolli, A.; Ruggiu, M.W.; Manca, A.; Bassotti, G.; Pes, G.M. Helicobacter pylori eradication may influence timing of endoscopic surveillance for gastric cancer in patients with gastric precancerous lesions: A retrospective study. Medicine (Baltimore) 2018, 97, e9734. [CrossRef] 